\title{
OGRANICZENIA W CODZIENNYCH CZYNNOŚCIACH SPOWODOWANE BÓLAMI KRZYŻA ROLNIKÓW INDYWIDUALNYCH Z PÓŁNOCNEJ LUBELSZCZYZNY
}

\section{RESTRICTIONS IN DAILY ACTIVITIES CAUSED BY THE BACKACHE SUFFERED BY FARMERS FROM NORTHERN LUBLIN PROVINCE}

\author{
Dorota Tomczyszynn $^{1(\mathrm{~B}, \mathrm{C}, \mathrm{D}, \mathrm{E}, \mathrm{F})}$, Anna Pańczuk ${ }^{2(\mathrm{~B}, \mathrm{C}, \mathrm{D}, \mathrm{E}, \mathrm{F})}$, Leszek Solecki ${ }^{3(\mathrm{~A}, \mathrm{C}, \mathrm{D}, \mathrm{E})}$ \\ ${ }^{1}$ Zakład Socjologii, Państwowa Szkoła Wyższa im. Papieża Jana Pawła II w Białej Podlaskiej \\ 2Zakład Fizjoterapii, Państwowa Szkoła Wyższa im. Papieża Jana Pawła II w Białej Podlaskiej \\ ${ }^{3}$ Zakład Zdrowia Publicznego, Państwowa Szkoła Wyższa im. Papieża Jana Pawła II w Białej Podlaskiej
}

Tomczyszyn, D., Pańczuk, A., Solecki, L. (2017). Ograniczenia w codziennych czynnościach spowodowane bólami krzyża rolników indywidualnych z północnej Lubelszczyzny. Rozprawy Społeczne, 11(4), 43-49. https://doi.org/10.29316/rs.2017.37

Wkład autorów:

A. Zaplanowanie badań

B. Zebranie danych

C. Dane - analiza i statystyki

D. Interpretacja danych

E. Przygotowanie artykułu

F. Wyszukiwanie i analiza literatury

G. Zebranie funduszy
Tabele: 4

Ryciny: 2

Literatura: 12

Otrzymano: lipiec 2017

Zaakceptowano: sierpień 2017

\begin{abstract}
Streszczenie
Wstęp. Celem badań była analiza ograniczeń w wykonywaniu codziennych osobistych czynności rolników indywidualnych, odczuwających bóle w dolnej części kręgosłupa.

Materiał i metody. Przebadano 108 mężczyzn pracujących w zawodzie rolnika w północnej części województwa lubelskiego. Do oceny ograniczeń w codziennych czynnościach spowodowanych bólami krzyża wykorzystano The Oswestry Disability Index, zwanym również The Oswestry Low Back Pain Disability Questionnaire

Wyniki. Wśród badanej grupy wyłoniono 93 osoby, które odczuwały bóle w dolnej części kręgosłupa, co stanowiło $86 \%$ wszystkich badanych. Ograniczenia spowodowane bólami krzyża i/ lub nasilenie dolegliwości bólowych, badani rolnicy najczęściej zgłosili w odniesieniu do dźwigania/podnoszenia oraz stania (po 83,9\%). Im dłuższy staż pracy na roli, tym częściej rolnicy odczuwają ból podczas podnoszenia ciężarów, siedzenia czy podróżowania.

Wnioski. Ważnym zadaniem staje się propagowanie wśród rolników możliwości uczestniczenia w programach promocji zdrowia i edukacji zdrowotnej z zakresu ergonomii pracy.

Słowa kluczowe: bóle kręgosłupa, ergonomia pracy, czynności codzienne, rolnicy

\section{Summary}

Introduction. The study aims to analyse the limitations of daily personal activities of farmers who experience pain in the lower part of the spine.

Material and methods. 108 men working as farmers in the northern part of Lublin Province were examined. The Oswestry Disability Index, also known as The Oswestry Low Back Pain Disability Questionnaire, was used to assess the limitations in daily activities caused by backaches. Results. Within the studied group, 93 people were identified as those suffering from lower back pain, which accounted for $86 \%$ of all the examined. The limitations caused by backaches and/ or aggravation of pain, were reported by the surveyed farmers most frequently in relation to carrying or lifting heavy objects as well as standing (83.9\%). The longer the farmers worked on the farm, the more often they felt pain while lifting weights, sitting or travelling.

Conclusions. It is vital to promote opportunities of health promotion and education programmes in formers in the field of ergonomics.
\end{abstract}

Keywords: spine pain, work ergonomics, daily activities, farmers

\section{Wstęp}

Dolegliwości mięśniowo-szkieletowe są w Europie najbardziej rozpowszechnionym problemem zdrowotnym związanym z pracą zawodową. Prawie 24\% pracowników z państw UE-25 skarży się na bóle kręgosłupa, a $22 \%$ na bóle mięśniowe. Schorzenia te są najbardziej powszechne w nowych państwach członkowskich, gdzie występują odpowied- nio u 39\% i 36\% pracowników (Europejska Agencja Bezpieczeństwa i Zdrowia w Pracy, 2007).

Przeciążenia kręgosłupa osób pracujących fizycznie dotyczą najczęściej odcinka lędźwiowego kręgosłupa (Gałuszka i in., 2015). Schorzenia tej części kręgosłupa występują $\mathrm{w}$ wielu gałęziach przemysłu i wielu zawodach, jednak najczęściej obserwowane są wśród: rolników, robotników budowlanych, cieśli, kierowców (w tym kierowców ciężarówek

Adres korespondencyjny: Dorota Tomczyszyn, Państwowa Szkoła Wyższa im. Papieża Jana Pawła II w Białej Podlaskiej, Zakład Socjologii, ul. Sidorska 102, 21-500 Biała Podlaska, e-mail: tomczyszyn@o2.pl, tel. 833449911

Copyright by: Państwowa Szkoła Wyższa im. Papieża Jana Pawła II w Białej Podlaskiej, Dorota Tomczyszyn, Anna Pańczuk, Leszek Solecki

Czasopismo Open Access, wszystkie artykuły udostępniane są na mocy licencji Creative Commons Uznanie autorstwa-użycie niekomercyjne-na tych samych warunkach 4.0 Międzynarodowe (CC BY-NC-SA 4.0, http://creativecommons.org/licenses/by-nc-sa/4.0/). 
i traktorzystów), pielęgniarek, sprzątaczek, itp. Osoby zatrudnione w rolnictwie narażone są na działanie wielu szkodliwych czynników środowiskowych. Do zagrożeń fizycznych i stresorów występujących w tym zawodzie należą m.in.: podnoszenie i przenoszenie ciężkich przedmiotów, ryzyko potknięcia i upadku na nierównym i śliskim podłożu, ryzyko wypadku spowodowane przez nagłe, nieprzewidywalne zachowania zwierząt, narażenie na hałas i wibracje przenoszone z pojazdów i mechanicznych urządzeń rolniczych na ciało (Solecki, 2014a)

Ograniczenia w codziennym funkcjonowaniu rolników spowodowane bólami lędźwiowego odcinka kręgosłupa stały się zjawiskiem powszechnym. Ten problem społeczny i medyczny dość często opisywany jest w literaturze (Depa, Drużbicki, 2008, Rutkowska, 2003, Gałuszka i in., 2015, Solecki, 2014a, Solecki, 2014b). Rzadziej zwraca się uwagę na charakterystykę i specyfikę samych ograniczeń, zwłaszcza tych, które dotyczą codziennych, osobistych czynności każdego człowieka, typu: samoobsługa, siedzenie, stanie, chodzenia, podróżowanie i itp.

\section{Cel pracy}

Celem badań była analiza ograniczeń w wykonywaniu codziennych, osobistych czynności wśród rolników indywidualnych, odczuwających bóle w dolnej części kręgosłupa z uwzględnieniem stażu pracy badanych rolników.

\section{Materiał i metoda}

W badaniach wzięło udział 108 mężczyzn pracujących w zawodzie rolnika w północnej części województwa lubelskiego. Gospodarstwa badanych rolników miały powierzchnię nie mniejszą niż 10 ha. W doborze grupy badawczej założono także, że praca w rolnictwie stanowi jedyny wykonywany zawód. Wśród tej grupy wyłoniono 93 osoby, które odczuwały bóle w dolnej części kręgosłupa, co stanowiło $86 \%$ wszystkich badanych. Dalsze analizy dotyczą tej grupy rolników, czyli 93 osób.

W badaniach zastosowano ankietę zawierającą pytania dotyczące wieku respondentów, aktualnego obszaru gospodarstwa i rodzaju produkcji rolnej, liczby lat pracy w zawodzie rolnika, liczby lat jazdy ciągnikami rolniczymi (maszynami samojezdnymi) i kierowania ciagnnikiem w pozycji z tułowiem skręconym do tyłu (obserwując pracę za ciągnikiem), oceny przez rolników ciężkości pracy we własnym gospodarstwie oraz ukończonych kursów dokształcających dotyczących wykonywanego zawodu. Do oceny ograniczeń w codziennych czynnościach spowodowanych bólami krzyża wykorzystano pytania zawarte w Kwestionariuszu oceny niepełnosprawności wywołanej bólami krzyża (The Oswestry Disability Index, zwanym również The Oswestry Low Back Pain Disability Questionnaire), w którym badani oceniali ból i/lub ograniczenia występujące w ciągu ostatniego tygodnia. Kwestionariusz ten składa się z dziesięciu domen, obejmujących: nasilenie bólu, samoobsługę, dźwiganie/podnoszenie, chodzenie, siedzenie, stanie, sen, życie seksualne, funkcjonowanie społeczne, podróżowanie.

Uzyskane dane zaprezentowano w postaci wartości procentowych. Do analizy ograniczeń w poszczególnych czynnościach względem stażu pracy w rolnictwie wykorzystano test nieparametryczny $\mathrm{Chi}^{2}$ Pearsona. Jako wartość stanowiącą istotność statystyczną różnic przyjęto $\mathrm{p} \leq 0,05$.

\section{Charakterystyka rolników, którzy odczuwali bóle w dolnej części kręgosłupa ( $\mathrm{N}=93)$}

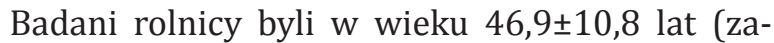
kres: 22-70 lat). Zajmowali się produkcją mieszaną (o charakterze roślinno-zwierzęcym). Posiadali średnio 29,0 $\pm 19,5$ ha ziemi wraz z gruntami dzierżawionymi. Staż pracy rolników w zawodzie to średnio $25,5 \pm 10,5$ lat. Ciągnikami rolniczymi (i maszynami samojezdnymi) jeździło 91 osób, średnio 25,2 $\pm 10,1$ lat (zakres: 0-50 lat).

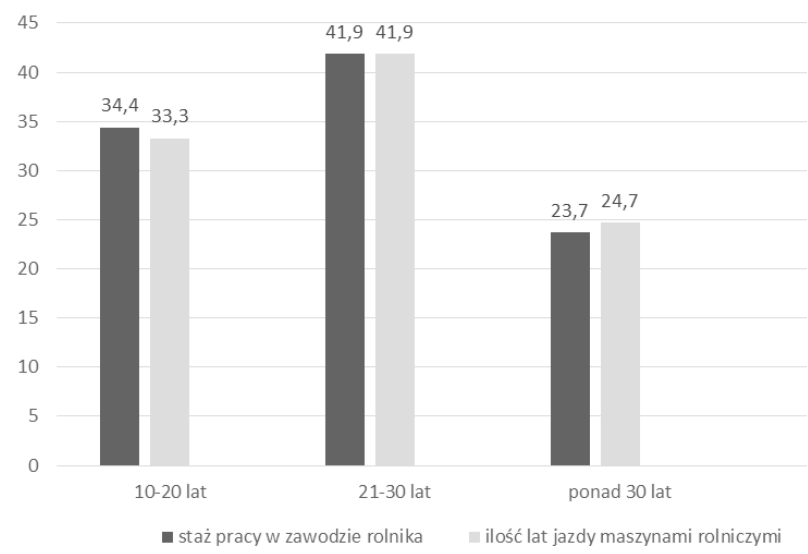

Rycina 1. Staż pracy w zawodzie i ilość lat jazdy maszynami rolniczymi $(\%)$

Źródło: badania własne.

Jak wynika z danych przedstawionych na wykresie 1 staż pracy w rolnictwie jest zbliżony do liczby lat jazdy maszynami rolniczymi. W związku $\mathrm{z}$ tym założono, że od początku swojej pracy w zawodzie mężczyźni jeździli maszynami rolniczymi. Najliczniejszą grupę stanowili badani pracujący w zawodzie rolnika i jeżdżący maszynami rolniczymi od 21 do 30 lat. Kolejna grupa to rolnicy pracujący i jeżdżący ciągnikami do 20 lat.

Z dalszych analiz wynika, że zdecydowana większość - 80 osób $(87,9 \%)$ jeździła ciągnikiem z tułowiem skręconym do tyłu, obserwując pracę za ciągnikiem, a tylko 11 rolników $(12,1 \%)$ podczas jazdy ciągnikiem nie skręcało tułowia do tyłu.

Blisko połowa badanej grupy uczestniczyła w różnych specjalistycznych kursach dokształcających (46 osób, co stanowi 49,5\%). Były to zazwyczaj kursy kwalifikacji rolniczej; na przykład kurs kombajnisty, kurs chemizacyjny, hodowli krów mlecznych także studia na kierunkach rolniczych. 


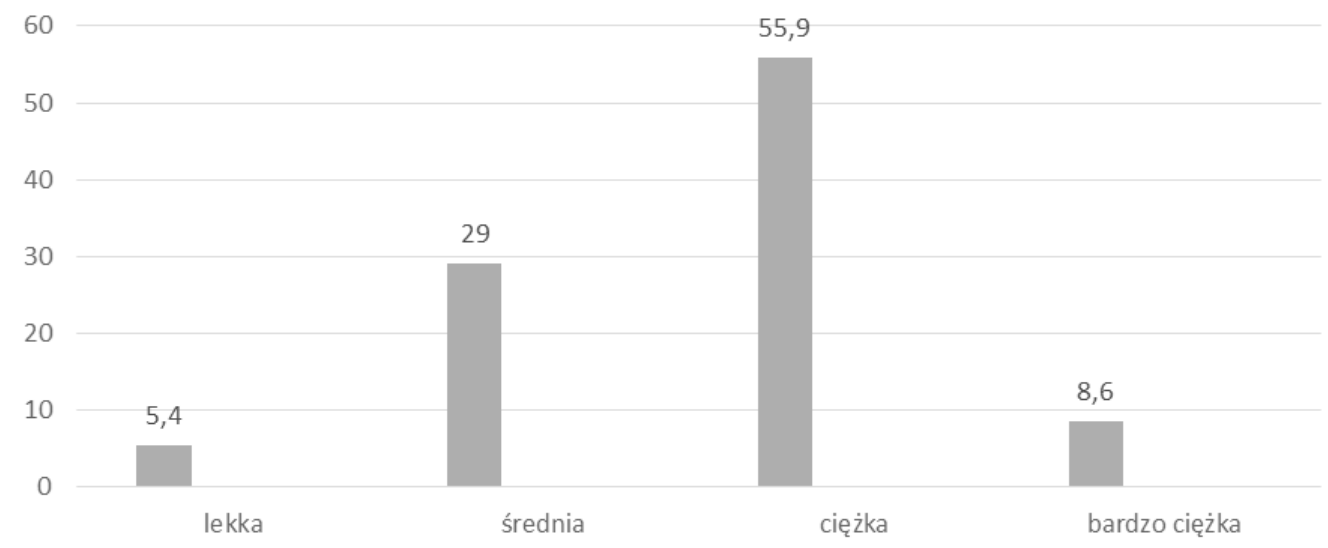

Rycina 2. Ocena pracy we własnym gospodarstwie rolnym (\%) Źródło: badania własne.

Dokonując oceny pracy we własnym gospodarstwie rolnym, największa część grupy sugerowała, że praca rolnika jest ciężka 55,9\%, co trzecia osoba wskazywała, że jest lekka lub średnia 34,9\%. Pozostałe $8,6 \%$ badanych oceniało ją jako bardzo ciężką.

\section{Wyniki}

Wyniki dokonanej przez badanych rolników oceny bólu i/lub ograniczeń wywołanych bólami krzyża, występujących w ciągu ostatniego tygodnia, zamieszczono w tabeli 1 . Oceniając nasilenie bólu krzyża w ciągu ostatniego tygodnia, większość badanych $(60,2 \%)$ oświadczyła, iż ból, który odczuwali był do zniesienia lub był nieprzyjemny, ale można go było znieść bez potrzeby brania środków przeciwbólowych. Zastosowanie środków przeciwbólowych, które przyniosły zupełną ulgę $\mathrm{w}$ bólu zadeklarowało $30,1 \%$ badanych, a 8,6\% oświadczyło, iż środki przeciwbólowe przyniosły umiarkowaną ulgę.

Tabela 1. Ocena bólu i/lub ograniczeń wywołanych bólami krzyża, występujących w ciągu ostatniego tygodnia wśród badanych rolników (pytania na podstawie kwestionariusza oceny niepełnosprawności wywołanej bólami krzyża - The Oswestry Low Back Pain Disability Questionnaire)

\begin{tabular}{|c|c|}
\hline Nasilenie bólu & $\%$ \\
\hline Mogę znosić ból, który odczuwam bez potrzeby zażywania środków przeciwbólowych & 30,1 \\
\hline Ból jest nieprzyjemny, ale mogę go znosić bez brania środków przeciwbólowych & 30,1 \\
\hline Środki przeciwbólowe przynoszą zupełną ulgę w bólu & 30,1 \\
\hline Środki przeciwbólowe przynoszą umiarkowaną ulgę w bólu & 8,6 \\
\hline Środki przeciwbólowe przynoszą niewielką ulgę w bólu & 0,0 \\
\hline Środki przeciwbólowe nie zmniejszają bólu i dlatego ich nie używam & 1,1 \\
\hline \multicolumn{2}{|l|}{ Samoobsługa (mycie się, ubieranie itd.) } \\
\hline Mogę wykonywać czynności samoobsługowe normalnie, bez powodowania dodatkowego bólu & 52,7 \\
\hline Mogę wykonywać czynności samoobsługowe normalnie, ale powoduje to dodatkowy ból & 23,7 \\
\hline Czynności samoobsługowe powodują ból, więc jestem powolny i ostrożny przy ich wykonywaniu & 16,1 \\
\hline Czasem potrzebuję pomocy, ale większość czynności samoobsługowych wykonuję sam & 7,5 \\
\hline Potrzebuję codziennej pomocy przy wykonywaniu większości czynności samoobsługowych & 0,0 \\
\hline Nie jestem w stanie się ubrać, myję się z trudnością i pozostaję w łóżku & 0,0 \\
\hline \multicolumn{2}{|l|}{ Dźwiganie/podnoszenie } \\
\hline Mogę podnosić ciężkie przedmioty bez dodatkowego bólu & 16,1 \\
\hline Mogę podnosić ciężkie przedmioty, ale sprawia to ból & 54,8 \\
\hline Ból nie pozwala mi podnosić ciężkich przedmiotów z podłogi, ale mogę to robić gdy są odpowiednio ułożone, np. na stole & 15,1 \\
\hline $\begin{array}{l}\text { Ból nie pozwala mi podnosić ciężkich przedmiotów z podłogi, ale mogę podnosić lekkie lub średniej wagi, gdy są odpo- } \\
\text { wiednio ułożone }\end{array}$ & 10,8 \\
\hline Mogę podnosić jedynie bardzo lekkie przedmioty & 1,1 \\
\hline Nie mogę dźwigać ani nosić żadnych ciężarów & 2,1 \\
\hline \multicolumn{2}{|l|}{ Chodzenie } \\
\hline Ból nie przeszkadza mi w pokonywaniu dowolnych dystansów & 48,4 \\
\hline Ból przeszkadza mi w pokonywaniu dystansów dłuższych niż kilometr & 36,6 \\
\hline
\end{tabular}




\begin{tabular}{|c|c|}
\hline Ból przeszkadza mi w pokonywaniu dystansów dłuższych niż pół kilometra & 8,6 \\
\hline Ból przeszkadza mi w pokonywaniu dystansów dłuższych niż 250 metrów & 6,4 \\
\hline Mogę chodzić jedynie używając laski lub kul & 0,0 \\
\hline Większość czasu leżę w łóżku i muszę czołgać się, kiedy chcę pójść do toalety & 0,0 \\
\hline \multicolumn{2}{|l|}{$\begin{array}{ll} & \text { Siedzenie } \\
\end{array}$} \\
\hline Mogę siedzieć na dowolnym krześle tak długo, jak chcę & 24,7 \\
\hline Tylko na moim ulubionym krześle mogę siedzieć tak długo jak chcę & 15,1 \\
\hline Ból przeszkadza mi w siedzeniu dłuższym niż 1 godzina & 43,0 \\
\hline Ból przeszkadza mi w siedzeniu dłuższym niż pół godziny & 15,1 \\
\hline Ból przeszkadza mi w siedzeniu dłuższym niż 10 minut & 1,1 \\
\hline Ból w ogóle nie pozwala mi siedzieć & 1,1 \\
\hline \multicolumn{2}{|l|}{ Stanie } \\
\hline Mogę stać tak długo jak chcę i nie powoduje to dodatkowego bólu & 16,1 \\
\hline Mogę stać tak długo jak chcę, ale powoduje to dodatkowy ból & 34,4 \\
\hline Ból nie pozwala mi stać dłużej niż 1 godzinę & 21,5 \\
\hline Ból nie pozwala mi stać dłużej niż 30 minut & 22,6 \\
\hline Ból nie pozwala mi stać dłużej niż 10 minut & 5,4 \\
\hline Ból w ogóle nie pozwala mi stać & 0,0 \\
\hline \multicolumn{2}{|l|}{ Sen } \\
\hline Ból w ogóle nie zaburza mojego snu & 59,1 \\
\hline Śpię dobrze tylko wtedy, kiedy zażyję tabletki & 21,5 \\
\hline Nawet kiedy wezmę tabletki, śpię mniej niż 6 godzin & 15,1 \\
\hline Nawet kiedy wezmę tabletki, śpię mniej niż 4 godziny & 1,1 \\
\hline Nawet kiedy wezmę tabletki, śpię mniej niż 2 godziny & 1,1 \\
\hline Ból w ogóle nie pozwala mi spać & 2,1 \\
\hline \multicolumn{2}{|l|}{ Życie seksualne } \\
\hline Moje życie seksualne wygląda tak jak zwykle i nie powoduje dodatkowego bólu & 57,0 \\
\hline Moje życie seksualne wygląda tak jak zwykle, ale powoduje nasilenie bólu & 23,7 \\
\hline Moje życie seksualne wygląda w przybliżeniu tak jak zwykle, ale powoduje znaczne nasilenie bólu & 9,7 \\
\hline Moje życie seksualne jest mocno ograniczone przez ból & 5,4 \\
\hline Moje życie seksualne prawie nie istnieje z powodu bólu & 2,1 \\
\hline Ból w ogóle nie pozwala mi prowadzić życia seksualnego & 2,1 \\
\hline \multicolumn{2}{|l|}{ Funkcjonowanie społeczne } \\
\hline Moje funkcjonowanie społeczne jest takie jak zawsze i nie powoduje dodatkowego bólu & 44,1 \\
\hline Moje funkcjonowanie społeczne jest takie jak zawsze, ale powoduje nasilenie bólu & 26,9 \\
\hline Ból nie ma dużego wpływu na moje funkcjonowanie społeczne z wyjątkiem tańca wymagającego dużej energii & 15,1 \\
\hline Ból ogranicza moje funkcjonowanie społeczne i nie wychodzę już tak często jak kiedyś & 12,9 \\
\hline Ból ograniczył moje funkcjonowanie społeczne do mojego domu & 0,0 \\
\hline Nie prowadzę w ogóle życia społecznego z powodu bólu & 1,1 \\
\hline \multicolumn{2}{|l|}{ Podróżowanie } \\
\hline Mogę podróżować wszędzie i nie powoduje to dodatkowego bólu & 30,1 \\
\hline Mogę podróżować wszędzie, ale powoduje to dodatkowy ból & 30,1 \\
\hline Ból jest nieprzyjemny, ale jestem w stanie podróżować dłużej niż 2 godziny & 30,1 \\
\hline Ból ogranicza mnie do podróży krótszych niż 1 godzina & 8,6 \\
\hline Ból ogranicza mnie do niezbędnych podróży krótszych niż 30 minut & 0,0 \\
\hline Ból nie pozwala mi w ogóle podróżować z wyjątkiem wizyt u lekarza & 1,1 \\
\hline
\end{tabular}

Spośród analizowanych czynności, ograniczenia spowodowane bólami krzyża i/lub nasilenie dolegliwości bólowych, badani najczęściej zgłosili w odniesieniu do dźwigania/podnoszenia oraz stania (po 83,9\%). W dalszej kolejności było to siedzenie $(75,3 \%)$, podróżowanie $(69,9 \%)$, funkcjonowanie społeczne $(55,9 \%)$ i chodzenie $(51,6 \%)$. Mniej niż połowa badanych oświadczyła, iż ból krzyża powodował ograniczenia i/lub nasilenie bólu w odniesieniu do samoobsługi (mycia się, ubierania itd.) (47,3\%), życia seksualnego $(43,0 \%)$ oraz snu $(40,9 \%)$. 
W zakresie dźwigania/podnoszenia, które wraz ze staniem było czynnością przy wykonywaniu której najczęściej zgłaszano ograniczenia, 54,8\% badanych rolników zadeklarowało, iż może podnosić ciężkie przedmioty, ale sprawia im to ból. Co czwarty badany oświadczył, że ból nie pozwala podnosić ciężkich przedmiotów z podłogi, ale może to robić, gdy są odpowiednio ułożone, np. na stole $(15,1 \%)$ lub może podnosić przedmioty lekkie lub średniej wagi, gdy są odpowiednio ułożone $(10,8 \%)$. Oceniając ograniczenia dotyczące stania, najliczniejsza grupa badanych oświadczyła, iż może stać tak długo jak chce, ale powoduje to dodatkowy ból (34,4\%). Ból krzyża nie pozwala stać dłużej niż 1 godzinę 21,5\% badanych, dłużej niż 30 minut 22,6\%, natomiast 5,4\% zadeklarowało, iż nie są w stać dłużej niż 10 minut.

Badani rolnicy najrzadziej zgłaszali ograniczenia dotyczące snu. Wśród osób, które zgłosiły zaburzenia snu spowodowane bólami krzyża, najliczniejsza grupa oświadczyła, iż śpi dobrze tylko wtedy, kiedy zażyje tabletki (21,5\% ogółu); $15,1 \%$ badanych nawet kiedy weźmie tabletki, śpi mniej niż 6 godzin, a 4,4\% po zażyciu tabletek śpi krócej niż 2-4 godziny lub ból nie pozwala im spać.

Analiza ograniczeń w poszczególnych czynnościach względem stażu pracy w rolnictwie wykazała istotne zależności w odniesieniu do dźwigania/podnoszenia (tab. 2), siedzenia (tab. 3) oraz podróżowania (tab. 4).

Tabela 2. Ograniczenia w podnoszeniu ciężarów/dźwiganiu a staż pracy w rolnictwie (\%)

\begin{tabular}{|c|c|c|c|}
\hline Dźwiganie/podnoszenie & $\begin{array}{l}\text { Od } 10 \text { do } \\
20 \text { lat }\end{array}$ & $\begin{array}{l}\text { Od } 21 \text { do } \\
30 \text { lat }\end{array}$ & $\begin{array}{l}\text { Ponad } \\
30 \text { lat }\end{array}$ \\
\hline Mogę podnosić ciężkie przedmioty bez dodatkowego bólu & 28,1 & 12,8 & 4,6 \\
\hline Mogę podnosić ciężkie przedmioty, ale sprawia to ból & 53,1 & 59,0 & 50,0 \\
\hline $\begin{array}{l}\text { Ból nie pozwala mi podnosić ciężkich przedmiotów z podłogi, ale mogę to robić gdy } \\
\text { są odpowiednio ułożone, np. na stole }\end{array}$ & 15,6 & 15,4 & 13,6 \\
\hline $\begin{array}{l}\text { Ból nie pozwala mi podnosić ciężkich przedmiotów z podłogi, ale mogę podnosić } \\
\text { lekkie lub średniej wagi, gdy są odpowiednio ułożone }\end{array}$ & 3,1 & 12,8 & 18,2 \\
\hline Mogę podnosić jedynie bardzo lekkie przedmioty & 0,0 & 0,0 & 4,6 \\
\hline Nie mogę dźwigać ani nosić żadnych ciężarów & 0,0 & 0,0 & 9,1 \\
\hline Razem & 100,0 & 100,0 & 100,0 \\
\hline
\end{tabular}

Chi kwadrat Pearsona 17,919, df=10, p=0,05

Źródło: badania własne.

Istnieje niewielka zależność pomiędzy możliwością podnoszenia ciężarów a stażem pracy w rolnictwie. W każdej z wyodrębnionych grup stażu pracy największy odsetek badanych rolników wskazywał, iż odczuwają ból przy podnoszeniu ciężkich przedmiotów. Jedynie wśród rolników o stażu pracy ponad 30 lat wystąpiły osoby zgłaszające fakt, że nie mogą dźwigać żadnych przedmiotów lub tylko lekkie przedmioty. Im większy staż pracy tym większy odsetek tych osób, którym ból nie pozwala podnosić ciężkich przedmiotów z podłogi. W grupie rolników o najmniejszym stażu pracy (od 10 do 20 lat) najczęściej wskazywano, że podnoszenie przedmiotów nie sprawia żadnego bólu. (Tab. 2)

Tabela 3. Ograniczenia w czynności siedzenia a staż pracy w rolnictwie (\%)

\begin{tabular}{|c|c|c|c|}
\hline Siedzenie & $\begin{array}{c}\text { Od } 10 \text { do } \\
20 \text { lat }\end{array}$ & $\begin{array}{c}\text { Od } 21 \text { do } \\
30 \text { lat } \\
\end{array}$ & $\begin{array}{c}\text { Ponad } 30 \\
\text { lat }\end{array}$ \\
\hline Mogę siedzieć na dowolnym krześle tak długo, jak chcę & 34,4 & 25,6 & 9,1 \\
\hline Tylko na moim ulubionym krześle mogę siedzieć tak długo jak chcę & 21,9 & 5,1 & 22,7 \\
\hline Ból przeszkadza mi w siedzeniu dłuższym niż 1 godzina & 37,5 & 53,9 & 31,8 \\
\hline Ból przeszkadza mi w siedzeniu dłuższym niż pół godziny & 6,3 & 12,8 & 31,8 \\
\hline Ból przeszkadza mi w siedzeniu dłuższym niż 10 minut & 0,0 & 0,0 & 4,6 \\
\hline Ból w ogóle nie pozwala mi siedzieć & 0,0 & 2,6 & 0,0 \\
\hline Razem & 100,0 & 100,0 & 100,0 \\
\hline
\end{tabular}

Chi kwadrat Pearsona 20,222, df=10, p=0,03

Źródło: badania własne.

Stwierdzono istotne zależności między stażem pracy w rolnictwie a stopniem odczuwania bólu podczas siedzenia. We wszystkich wyodrębnionych grupach ze względu na staż pracy najczęściej wskazywano, że ból przeszkadza w siedzeniu powyżej godziny, jednak to rolnicy pracujący ponad 30 lat wskazywali częściej, że ból występuje przy siedzeniu dłuższym niż 30 minut, natomiast rolnicy o najkrótszym stażu pracy częściej twierdzili, że nie odczuwają żadnych dolegliwości podczas siedzenia (Tab. 3). 
Tabela 4. Ograniczenia w podróżowaniu a staż pracy w rolnictwie (\%)

\begin{tabular}{|l|c|c|c|}
\hline \multicolumn{1}{|c|}{ Podróżowanie } & $\begin{array}{c}\text { Od 10 do } \\
\mathbf{2 0} \text { lat }\end{array}$ & $\begin{array}{c}\text { Od 21 do } \\
\mathbf{3 0} \text { lat }\end{array}$ & $\begin{array}{c}\text { Ponad } \\
\mathbf{3 0} \text { lat }\end{array}$ \\
\hline Mogę podróżować wszędzie i nie powoduje to dodatkowego bólu & 46,9 & 25,6 & 13,6 \\
\hline Mogę podróżować wszędzie, ale powoduje to dodatkowy ból & 28,1 & 30,8 & 31,8 \\
\hline Ból jest nieprzyjemny, ale jestem w stanie podróżować dłużej niż 2 godziny & 21,9 & 38,5 & 27,3 \\
\hline Ból ogranicza mnie do podróży krótszych niż 1 godzina & 3,1 & 5,1 & 22,7 \\
\hline Ból ogranicza mnie do niezbędnych podróży krótszych niż 30 minut & 0,0 & 0,0 & 0,0 \\
\hline Ból nie pozwala mi w ogóle podróżować z wyjątkiem wizyt u lekarza lub w szpitalu & 0,0 & 0,0 & 4,6 \\
\hline \multicolumn{1}{|c|}{ Razem } & 100,0 & 100,0 & 100,0 \\
\hline
\end{tabular}

Chi kwadrat Pearsona 16,974, $\mathrm{df}=8, \mathrm{p}=0,03$

Źródło: badania własne.

Zaobserwowano związek między opiniami rolników na temat podróżowania a ich stażem pracy w rolnictwie. Im dłuższy staż pracy tym częściej rolnicy odczuwają dyskomfort i ból podczas podróżowania. Można zauważyć, że rolnicy pracujący najkrócej (od 10 do 20 lat) mogą podróżować wszędzie. Rolnicy o stażu od 20 do 30 lat twierdzili, że nieprzyjemny ból jest odczuwają podczas jazy powyżej 2 godzin. Odpowiedzi części rolników pracujących najdłużej wskazują, że odczuwają ból już przy podróży krótszych niż 30 minut (tab. 4).

\section{Dyskusja}

Wskazuje się na powszechność występowania bólów kręgosłupa u rolników w odniesieniu do przeciętnej populacji pracowników innych działów gospodarki (np. Suchoczewski, 2004).

A. Depa i M. Drużbicki oceniali częstość występowania zespołów bólowych lędźwiowego odcinka kręgosłupa w zależności od charakteru wykonywanej pracy. Porównywali pracowników umysłowych i fizycznych (łącznie 197 osób). Stwierdzili, że bóle lędźwiowego odcinak kręgosłupa dotyczą w szczególności mężczyzn wykonujących zawody fizyczne (Depa, Drużbicki, 2008).

Bóle lędźwiowego odcinka kręgosłupa mogą prowadzić do ograniczeń w życiu codziennym (Kiwerski, 2001). Akcentuje się, że mogą powodować niezdolność do pracy a także trwałą niepełnosprawność (Białachowski, Stryła, 2002).

Ograniczenia w codziennym funkcjonowaniu rolników spowodowane bólami lędźwiowego odcinak kręgosłupa stały się zjawiskiem powszechnym. Nie bez znaczenia jest tu charakter wykonywanej pracy, dźwiganie, powtarzanie niektórych ruchów oraz długo utrzymującej się postawy z tułowiem skręconym do tylu (praca z wykorzystaniem ciągnika) (Gałuszka i in. 2015).

Wśród badanych rolników zaobserwowano ograniczenia spowodowana bólami krzyża we wszystkich analizowanych czynnościach. Dotyczyły one najczęściej dźwigania/podnoszenia oraz stania, w dalszej kolejności siedzenia i podróżowania. Rolnicy najrzadziej zgłaszali ograniczenia w zakresie życia seksualnego i podczas snu.

Ważnym zadaniem staje się propagowanie wśród rolników możliwości uczestniczenia w programach promocji zdrowia, czy turnusach rehabilitacyjnych.
Skuteczność programów promujących zdrowy styl życia i turnusów rehabilitacyjnych potwierdzaja badania realizowane przez J. Bubińską na grupie 1100 rolników (Bubińska, 2009). Takie działania wydają się być szczególnie istotne $\mathrm{w}$ poprawie codziennego funkcjonowania tej grupy zawodowej. Zwłaszcza, iż wskazuje się, że rolnicy mieszkając w środowisku wiejskim mają utrudniony dostęp do porad specjalistów. Twierdzi się, że sami rolnicy najczęściej leczą objawy (stosując środki przeciwbólowe), a nie przyczyny dolegliwości (Rutkowska i in., 2001).

Występowanie dolegliwości bólowych kręgosłupa, głównie odcinka lędźwiowego, stanowi problem interdyscyplinarny. Praca z osobą doświadczającą tych trudności obejmuje nie tylko fizjoterapię czy farmakoterapię, ale także psychoterapię, edukację pacjenta i jego rodziny, zmianę ich stylu życia, pracy i wypoczynku (Dziak, 2004).

\section{Wnioski}

1. Ograniczenia spowodowane bólami krzyża i/lub nasilenie dolegliwości bólowych są zjawiskiem powszechnym $\mathrm{w}$ grupie rolników, badani rolnicy najczęściej zgłosili je w odniesieniu do dźwigania/podnoszenia oraz stania. W dalszej kolejności było to siedzenie oraz podróżowanie.

2. Istnieje istotny związek pomiędzy stażem pracy w rolnictwie a odczuwanymi ograniczeniach i/ lub nasileniem dolegliwości bólowych w zakresie podnoszeniem ciężarów, siedzenia oraz podróżowania. Im dłuższy staż pracy na roli, tym częściej rolnicy odczuwają ból podczas podnoszenia ciężarów, siedzenia czy podróżowania.

3. Ważnym zadaniem staje się propagowanie wśród rolników możliwości uczestniczenia w programach promocji zdrowia oraz turnusach rehabilitacyjnych. Zasady profilaktyki bólów kręgosłupa rolnicy powinni stosować w codziennej aktywności związanej z pracą i wypoczynkiem.

4. Wyniki badań powinny być także inspiracją dla producentów sprzętu i narzędzi rolniczych w zakresie ergonomicznej ich konstrukcji, co obok programów profilaktycznych kierowanych do samych rolników, może znacząco przyczynić się do ochrony kręgosłupa (i narządu ruchu) we wszelkich pracach w gospodarstwie rolnym. 


\section{Literatura:}

1. Białachowski, J.T., Stryła, W. (2002). Analiza wybranych cech antropometrycznych i rodzaju pracy zawodowej u chorych z przepukliną jadra miażdżystego części lędźwiowej kręgosłupa. Postępy Rehabilitacyjne, 16(1), 33-40.

2. Bubińska, J. (2009). Ocena efektywności programu rehabilitacji leczniczej rolników w wybranym centrum rehabilitacji KRUS. Polskie Annales Med., 16(1), 42-56.

3. Depa, A., Drużbicki, M. (2008). Ocena częstości występowania zespołów bólowych lędźwiowego odcinka kręgosłupa w zależności od charakteru wykonywanej pracy. Przegląd Medyczny Uniwersytetu Rzeszowskiego, 1, 34-41.

4. Dziak, A. (2004). Komentarz prof. dr hab. Andrzeja Dziaka do „Zaleceń stosowania fizjoterapii u pacjentów z bólami krzyża” wydanych przez Holenderskie Towarzystwo Fizjoterapii. Rehabilitacja Medyczna, 8, 28-30.

5. Europejska Agencja Bezpieczeństwa i Zdrowia w Pracy Factsheet 71 - Informacje wprowadzające na temat dolegliwości mięśniowo-szkieletowych związanych z pracą. Pobrane z: https://osha.europa.eu/pl/ tools-and-publications/publications/factsheets/71/view.

6. Gałuszka, R., Gałuszka, G., Miziałek, S. (2015). Zespoły bólowe kręgosłupa przeciążenia narządu ruchu u rolników-sadowników jako czynnik wpływający na dobrostan. Zdrowie i Dobrostan, 1, 113-122.

7. Kiwerski, J.E. (2001). Problem bólów krzyża u młodzieży. Postępowanie Rehabilitacyjne, 15(2), 11-15.

8. Rutkowska, E., Rola, R., Janusz, W., Kamieniak, P. (2001). Fizjoterapia w przedoperacyjnym leczeniu dyskopatii lędźwiowej. Fizjoterapia Polska, 1(4), 393-395.

9. Rutkowska, E. (2003). Radzenie sobie z bólami kręgosłupa w środowisku wiejskim. Annales UMCS, sectio D, LVIII, supl. XIII, 209, 39-44.

10. Solecki, L. (2014a). Przyczyny występowania dolegliwości bólowych ze strony układu mięśniowo-szkieletowego wśród rolników, w związku z wykonywaną pracą. Medycyna Ogólna i Nauki o Zdrowiu, 20(4), 426-429.

11. Solecki, L. (2014b). Complaints of low back pain among private farmers exposed to whole body vibration. Medycyna Pracy, 65(1), 55-64. https://doi.org/10.13075/mp.5893.2014.002

12. Suchoczewski, M. (2004). Epidemiologia bólu kręgosłupa lędźwiowo-krzyżowego w Polsce. Ból, 5, 44.

Uwaga: Badania przedstawione w powyższym artykule są częścią obszerniejszego projektu badawczego: Ocena stopnia niepełnosprawności oraz natężenia bólów pleców w dolnej części kręgosłupa wśród rolników indywidualnych. Z materiału zebranego w ramach tego projektu powstał również artykuł zatytułowany: Assessment of the type and intensity of low back pain and disability among individual farmers (status artykułu: przyjęty do publikacji w „Medycynie Pracy”). 